\title{
Implementasi Facebook Marketplace untuk Produk UMKM sebagai Upaya Peningkatan Pemasaran dan Penjualan Online
}

\author{
Implementation of Facebook Marketplace for MSME Products as an Effort to Increase
} Marketing and Online Sales

\author{
Ajib Susanto ${ }^{1}$, Christy Atika Sari ${ }^{2}$, De Rosal Ignatius Moses ${ }^{3}$, Eko Hari Rachmawanto ${ }^{4}$, Ibnu \\ Utomo Wahyu Mulyono 5 \\ 1,2,3,4,5 Teknik Informatika, Fakultas Ilmu Komputer, Universitas Dian Nuswantoro Semarang \\ E-mail: ${ }^{1}$ ajib.susanto@dsn.dinus.ac.id,${ }^{2}$ christy.atika.sari@dsn.dinus.ac.id, \\ ${ }^{3}$ moses@dsn.dinus.ac.id ${ }^{4}$ eko.hari.rachmawanto@dsn.dinus.ac.id , \\ 5ibnu.utomo.wm@dsn.dinus.ac.id
}

\begin{abstract}
Abstrak
Saat ini pemasaran dan penjualan hasil produk UMKM masih dilakukan dengan mengikuti berbagai macam pameran produk UMKM yang diadakan oleh pemerintah maupun perusahaan yang memberikan fasilitas pameran, melalui broadcast pesan dan menunggu pengunjung datang ke toko. Metode ini belum optimal dalam penyampaian informasi karena promosi yang dilakukan tidak menjangkau masyarakat yang berada jauh dari lokasi galeri pameran/toko. Media sosial saat ini menjadi alat yang sangat populer dan diminati oleh pelaku UMKM salah satunya adalah facebook yang di dalamnya terdapat fitur marketplace yang dapat menjangkau promosi dan penjualan yang tidak mengenal ruang dan waktu. Metode yang digunakan dalam penggunaan facebook marketplace dengan melakukan pelatihan langsung kepada pelaku UMKM untuk mem-posting produk, meng-share dan melayani pembelian konsumen. Hasil implementasi facebook marketplace memudahkan pelaku UMKM dalam memasarkan produk dan sekaligus melakukan penjualan dengan menggunakan smartphone yang dimiliki sehingga mampu meningkatkan volume penjualan.
\end{abstract}

Kata kunci: Facebook, Marketplace, UMKM, Penjualan, Online

\begin{abstract}
At present the marketing and selling of MSME products is still carried out by participating in various MSME product exhibitions held by the government and companies that provide exhibition facilities, through broadcast messages and waiting for visitors to come to the store. This method is not optimal in the delivery of information because the promotion does not reach people who are far from the location of the exhibition gallery / shop. Social media is currently a very popular tool and is in demand by SMEs, one of which is Facebook, which has a marketplace feature that can reach promotions and sales that are unfamiliar with space and time. The method used in using the Facebook marketplace is by conducting direct training for SMEs to post products, share and serve consumer purchases. The results of the implementation of the Facebook marketplace make it easier for SMEs to market their products and at the same time make sales using their smartphones so as to increase sales volume.
\end{abstract}

Keywords: Facebook, Marketplace, MSME, Sales, Online 


\section{PENDAHULUAN}

Perkembangan UMKM di Jateng yang tumbuh signifikan harus diikuti pula dengan perbaikan kualitas UMKM itu sendiri, agar mampu bersaing. Adapun saat ini, dari data BPS jumlah UMKM di Jateng telah mencapai 4,8 juta. Sedangkan dari data Dinkop Jateng, total telah ada 137.000 UMKM yang dibina oleh Dinkop[1].

Persoalan UMKM biasanya adalah masalah dengan modal, sumber daya manusia (SDM), bahan baku, pemasaran, dan manajemennya[1]. Saat ini pemasaran dan penjualan hasil produk UMKM masih dilakukan dengan mengikuti berbagai macam pameran produk UMKM yang diadakan oleh pemerintah maupun perusahaan yang memberikan fasilitas pameran, melalui broadcast pesan dan menunggu pengunjung datang ke toko. Metode ini belum optimal dalam penyampaian informasi karena promosi yang dilakukan tidak menjangkau masyarakat yang berada jauh dari lokasi galeri pameran/toko[2].

Kelompok Usaha Mikro, Kecil, Menengah (UMKM) di Jawa Tengah tergolong masih berdaya tawar rendah[3]. Banyaknya pengepul dalam rantai distribusi juga menyebabkan UMKM kurang berkembang, selain belum optimalnya penggunaan teknologi untuk mendukung produksi, pemasaran, penjualan maupun pengelolaan keuangannya. Salah satu yang belum dilakukan secara serius adalah pemasaran online melalui media internet atau biasa disebut internet marketing[4] yang jelas untuk kondisi saat ini akan sangat membantu meningkatkan promosi dan penjualan.

Perkembangan teknologi yang terus bergerak di era Industri 4.0[5] dan Society 5.0[5] ini mengakibatkan semua sektor harus mengikuti penggunaan teknologi yang sedang berkembang terutama dibidang teknologi informasi, penjualan online/e-commerce, media sosial dan smartphone, marketplace berupa aplikasi berbasis android seperti aplikasi M-Market[6], membuat aplikasi scraping[7] dari marketplace untuk kemudian diunggah ke marketplace yang lain atau e-commerce maupun berbagai macam startup marketplace seperti Shoope, Tokopedia serta berbagai content management system (CMS) yang tinggal diinstalasi gratis, belum dimanfaatkan dengan baik untuk mendukung perkembangan UMKM.

Berdasarkan data dari WeAreSocial[8] data pengguna internet di seluruh dunia adalah 4,388 milyar, yang terdaftar sebagai pengguna mobile adalah 5,112 milyar dari total penduduka dunia 7,676 milyar, yang aktif di media social berkisar 3,484 milyar. Indonesia salah satu negara yang mengalami perkembangan dengan penetrasi $56 \%$ aktif di media sosial, jumlah pengguna internet 150 juta dan aktif di media social 150 juta pengguna, merupakan pasar yang sangat potensial untuk UMKM yang akan memulai dan terus menggunakan media sosial untuk melakukan promosi dan penjualan online.

Terlepas dari kontroversi seputar privasi, peretasan, berita palsu, dan semua aspek negatif lain dari kehidupan online, dunia terus merangkul internet dan media sosial. Pertumbuhan digital global tidak menunjukkan tanda-tanda melambat, dengan sejuta orang baru di seluruh dunia datang online setiap hari. Pertumbuhan ini jelas memicu penggunaan media sosial, $45 \%$ dari populasi dunia sekarang adalah pengguna media sosial: 3,5 miliar orang[8].

Platform media sosial yang menyediakan tempat berjualan selain untuk berbagi cerita dan status adalah Facebook, yaitu dengan Facebook Marketplace yang dapat digunakan untuk menjual dan mempromosikan produk yang dapat menjangkau seluruh pengguna facebook. Walaupun jualan di Facebook itu juga ada pesaingnya, dibandingkan dengan jualan di platform e-commerce, persaingan di Facebook gak ketat-ketat amat. Makanya, cukup banyak orang yang cenderung berjualan di media sosial ini[9].

Dari berbagai kondisi UMKM saat ini dan jumlah yang terus meningkat diusulkan salah satu metode untuk pemasaran dan penjualan online melalui platform Facebook Marketplace yang penggunaannya cukup mudah, dapat dilakukan kapanpun dan di manapun serta dapat menjangkau ke seluruh pengguna Facebook sehingga promosi produk UMKM dan pelayanan penjualan online dapat dilakukan dengan mudah dan cepat yang nantinya secara tidak langsung akan meningkatkan penghasilan dari pelaku UMKM. 


\section{METODE PELAKSANAAN}

Tahapan metode penerapan Facebook Marketplace menggunakan tahapan dari konsep Plan, Do, Check and Act (PDCA)[10] yang merupakan proses yang berkelanjutan untuk perbaikan sistem selanjutnya, yang tahapannya dapat diuraikan sebagai berikut :

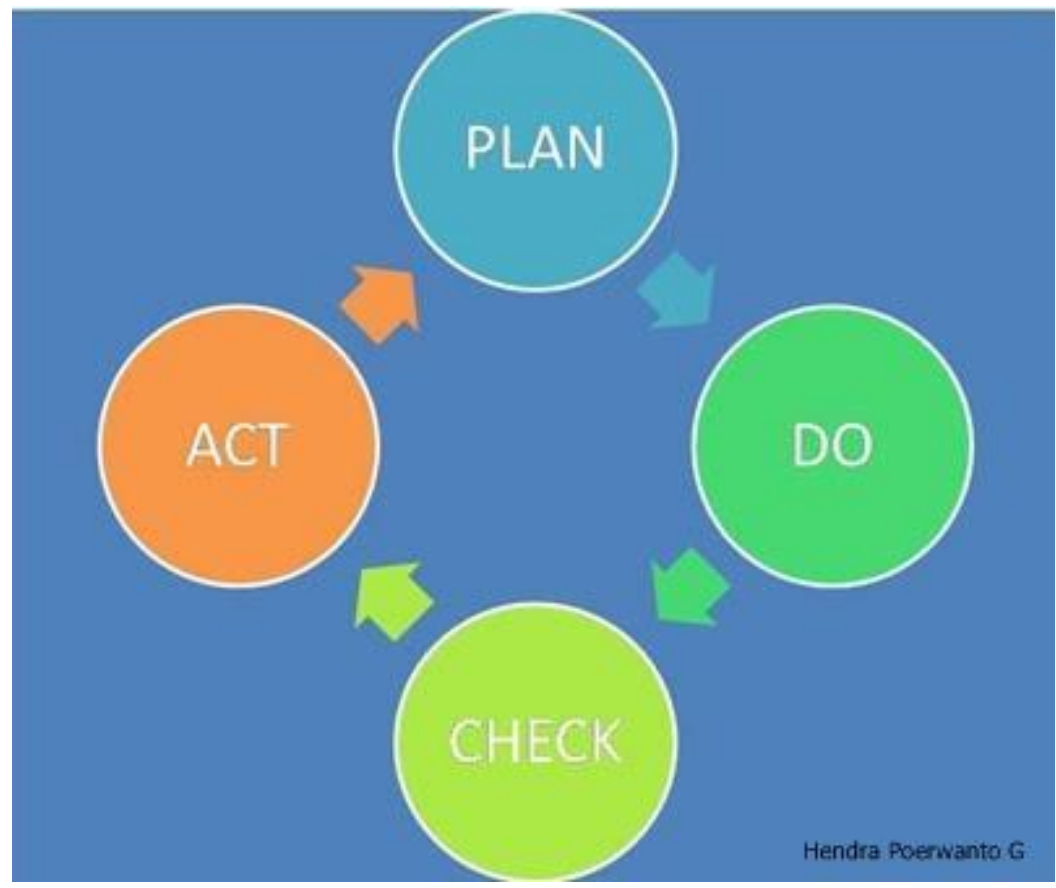

Gambar 1 Konsep PDAC

Konsep P-D-C-A diartikan sebagai proses untuk penyelesaian dan pengendalian masalah dengan model pola secara urut dan sistematis. Lebih jelas proses PDCA dapat diuraikan sebagai berikut:

\section{1. $\mathrm{P}($ Plan $=$ Rencanakan $)$}

Tahan ini adalah merencanakan tujuan (goal) dan proses apa saja yang dibutuhkan untuk menentukan hasil yang sesuai dengan spesifikasi tujuan yang ditetapkan. Pada tahap ini tujuan yang hendak dicapai yaitu membuat satu akun untuk melakukan promosi dan penjualan di Facebook Marketplace, sosialisasi dan menentukan tahap/proses yang akan dikerjakan.

2. $\mathrm{D}(D o=$ Kerjakan $)$

Tahap ini melakukan perencanaan proses yang telah ditetapkan sebelumnya, ukuran-ukuran proses ini juga telah ditetapkan dalam tahap perencanaan. Pada proses ini dihindari penundaan pekerjaan, mulai dari pengumpulan foto, deskripsi produk, harga dan kelangkapan lainnya. Kemudian dilaksanakan pelatihan Facebook Marketplace untuk mulai mengupload produk dan meng-share distatus dan diberbagai grup.

\section{C $($ Check $=$ Evaluasi $)$}

Tahap ini melakukan evaluasi terhadap sasaran dan proses serta melaporkan apa saja hasilnya. Mengecek kembali apa yang sudah dikerjakan, sudahkah sesuai dengan standar yang ada atau masih ada kekurangan. Pada tahap ini memantau perkembangan promosi dan penjualan di Facebook Marketplace dan menentukan hal apa lagi yang dapat digunakan untuk terus meningkatkan promosi dan penjualan online.

4. A $($ Act $=$ Menindaklanjuti $)$ 
Tahap ini melakukan evaluasi total terhadap hasil sasaran dan proses dan menindaklanjuti dengan perbaikan-perbaikan. jika ternyata apa yang telah dikerjakan masih ada yang kurang atau belum sempurna, segera melakukan tindakan untuk memperbaikinya. Proses ini sangat penting artinya sebelum melangkah lebih jauh ke proses perbaikan selanjutnya.

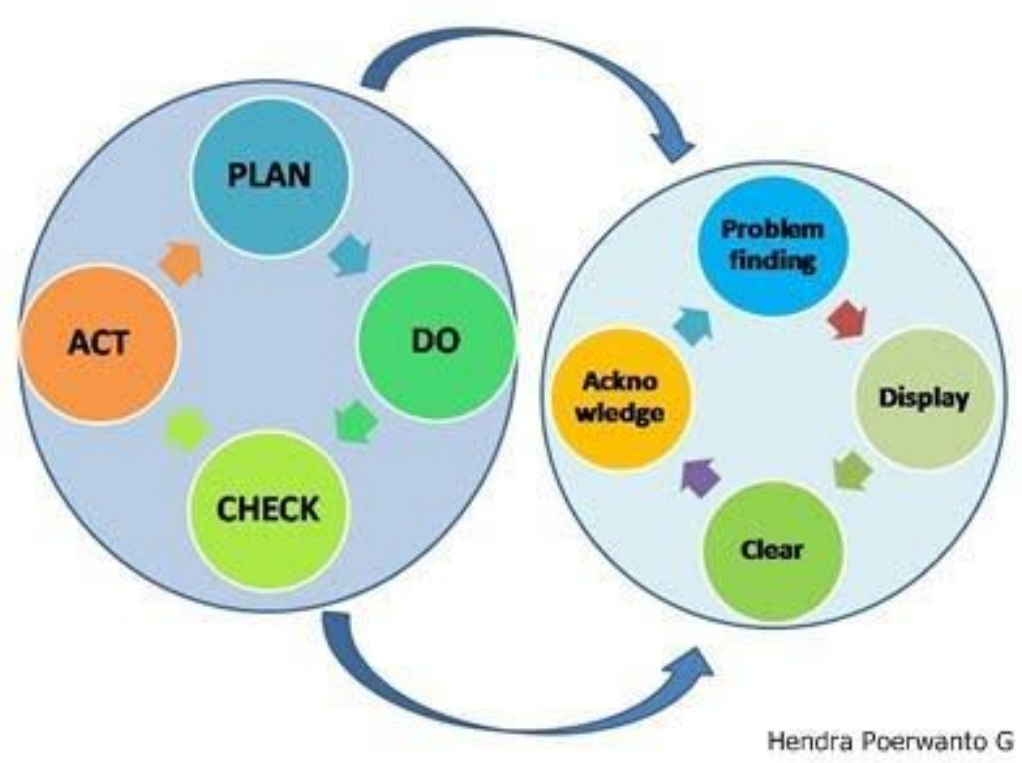

Gambar 2 Konsep PDCA dan Siklusnya

Gambar 2 menjelaskan bahwa hasil dari tahap-tahap proses PDCA kemudian digunakan untuk masukan bagi proses perencanaan lebih lanjut. Keempat proses yaitu Plan-Do-Check-Act $(P D C A)$ merupakan satu kesatuan siklus yang tidak dapat terputus dan saling berhubungan satu dengan yang lain.

\section{HASIL DAN PEMBAHASAN}

Implementasi Facebook Marketplace untuk promosi dan penjualan online UMKM berdasarkan konsep PDCA.

\subsection{Perencanaan}

Pada tahap ini dilakukan sosialisai, penentuan tujuan dan pengumpulan bahan serta mempelajari dan membandingkan proses penjualan di Facebook yang hanya promosi dan penjualan di grup-grup maupun di status FB. Gambar 3 ini menunjukkan proses penjualan yang dilakukan secara langsung atau direct sale di halaman status akun yang hanya dapat dilihat oleh pengguna FB yang sudah menjadi teman. Jangkauan informasi yang disebarkan hanya sebatas akun yang sudah menjadi teman sehingga perlu dioptimalkan dengan mem-posting produk di halaman FB Marketplace. 

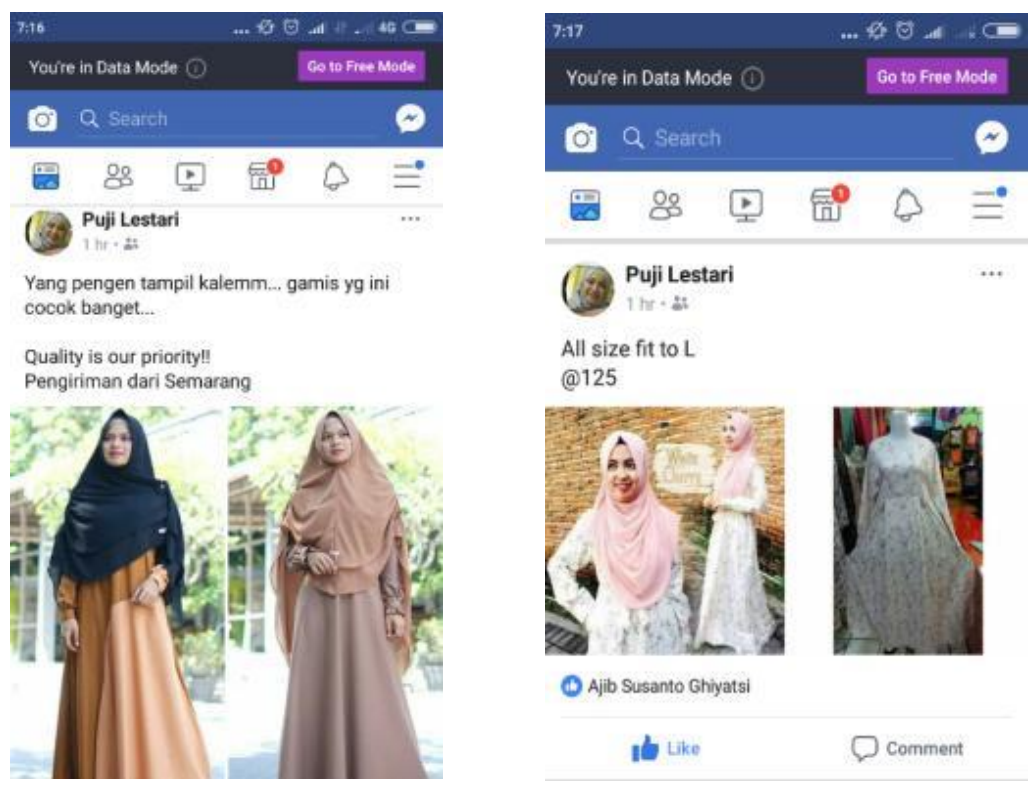

Gambar 3 Penjualan langsung di status FB

\subsection{Kerjakan}

Pada tahap ini mulai melakukan proses penjualan di FB Marketplace berdasarkan bahan-bahan yang dikumpulkan sebelumnya yaitu foto, deskripsi, harga serta akan di share ke grup apa saja.

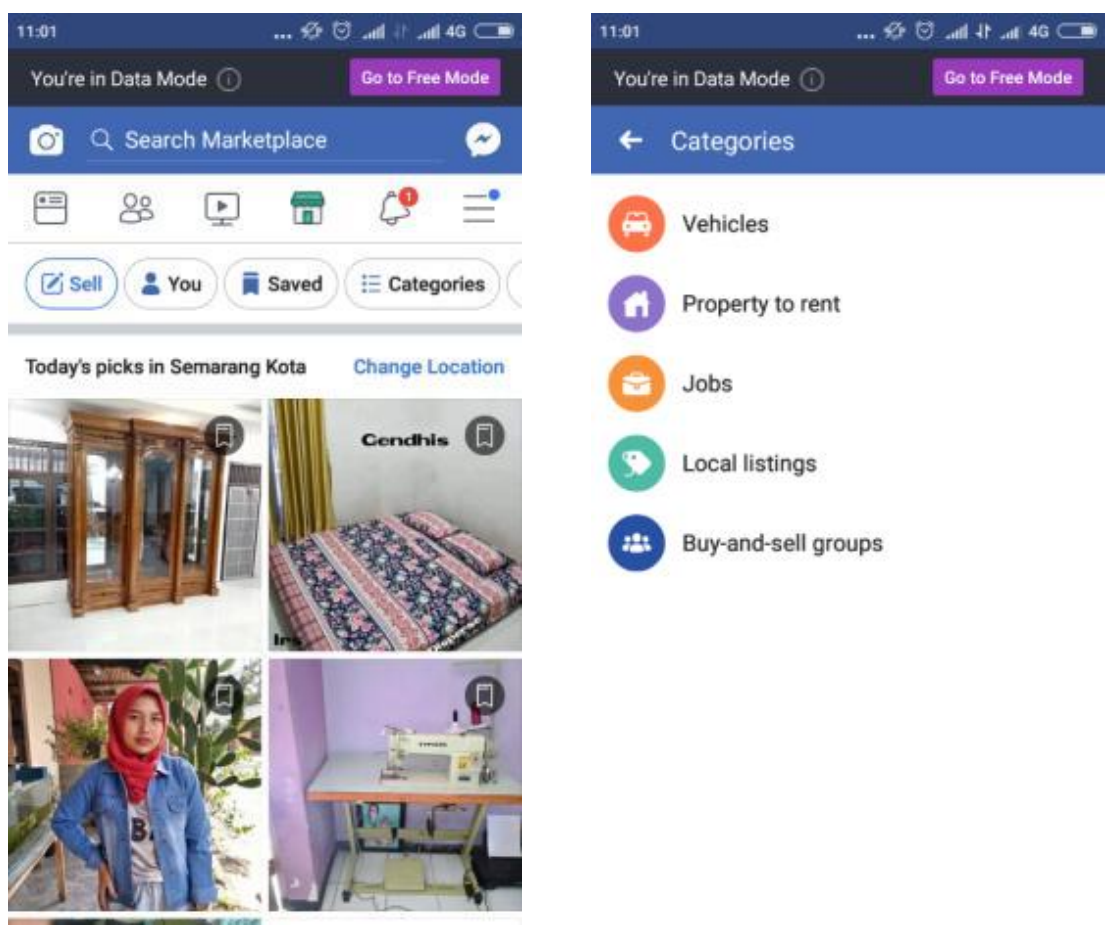

Gambar 4 Halaman depan FB Marketplace

Gambar 4 menunjukkan halaman awal FB Marketplace setelah mengklik icon FB Marketplace, dimana dimunculkan produk-produk yang sudah ter-upload, pengguna dapat mengecek kategori apa saja yang disajikan oleh FB Marketplace seperti kendaraan, rental, pekerjaan, daftar produk sesuai lokasi dan 
grup jual beli.
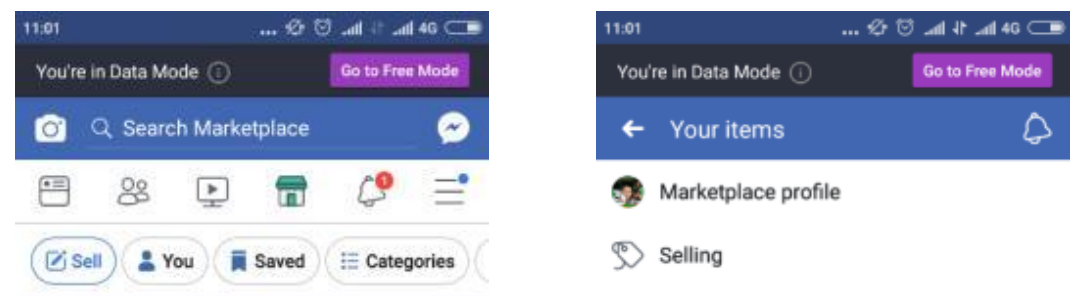

$$
\begin{aligned}
& \text { 2) Marketplace profile } \\
& \text { (D) Selling } \\
& \triangleright \text { Buying }
\end{aligned}
$$

Today's picks in Semarang Kota Change Location

$\nabla$ orders

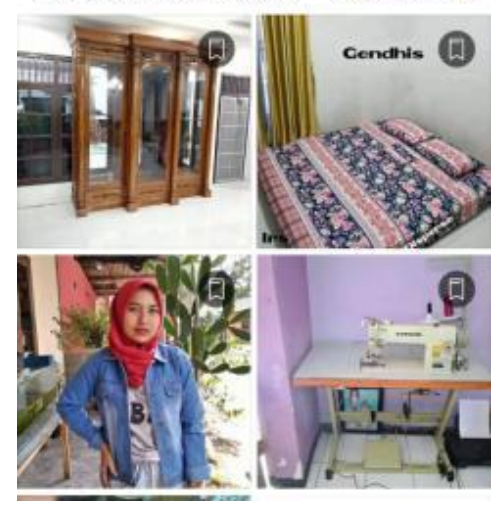

ఐ Saved

ה) Marketplace followers

20 Following

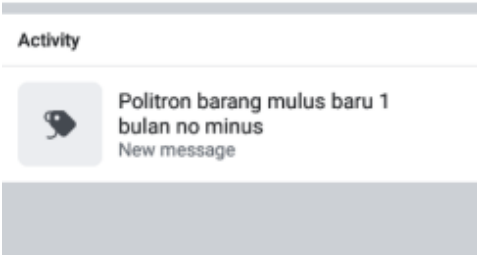

Gambar 5 Halaman Akun FB Marketplace \& Profile

Gambar 5 menampilkan halaman akun FB Marketplace \& Profile pengguna yang di dalamnya terdapat menu selling, buying, orders, saved, marketplace followers dan following.
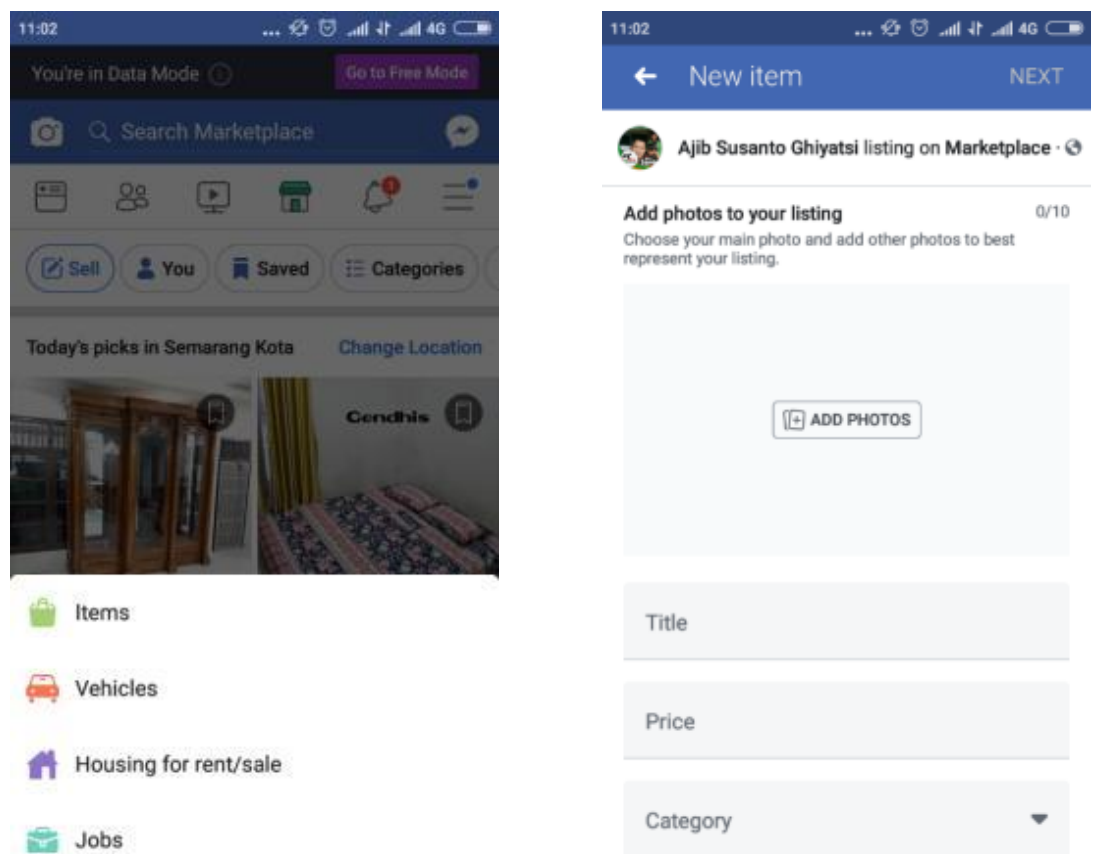

Gambar 6 Halaman Sell Items dan New Item

Gambar 6 di atas menjelaskan proses penjualan produk dengan memilih icon sell, memilih items sehingga muncul formulir untuk melengkapi data produk yang akan dijual. 


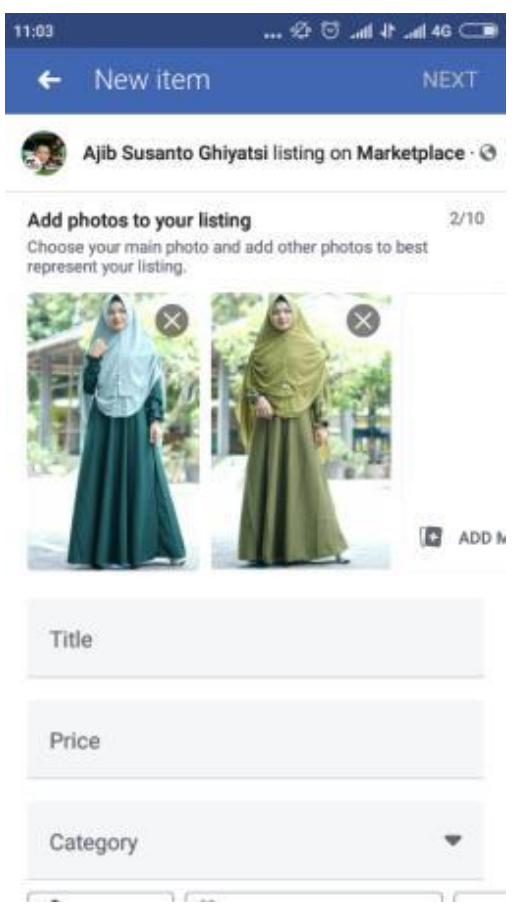

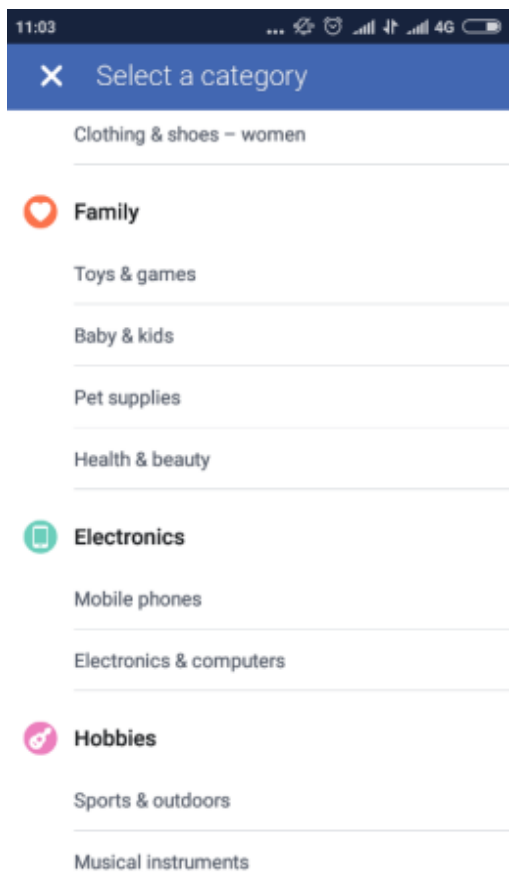

Gambar 7 Halaman Upload foto dan pilih kategori
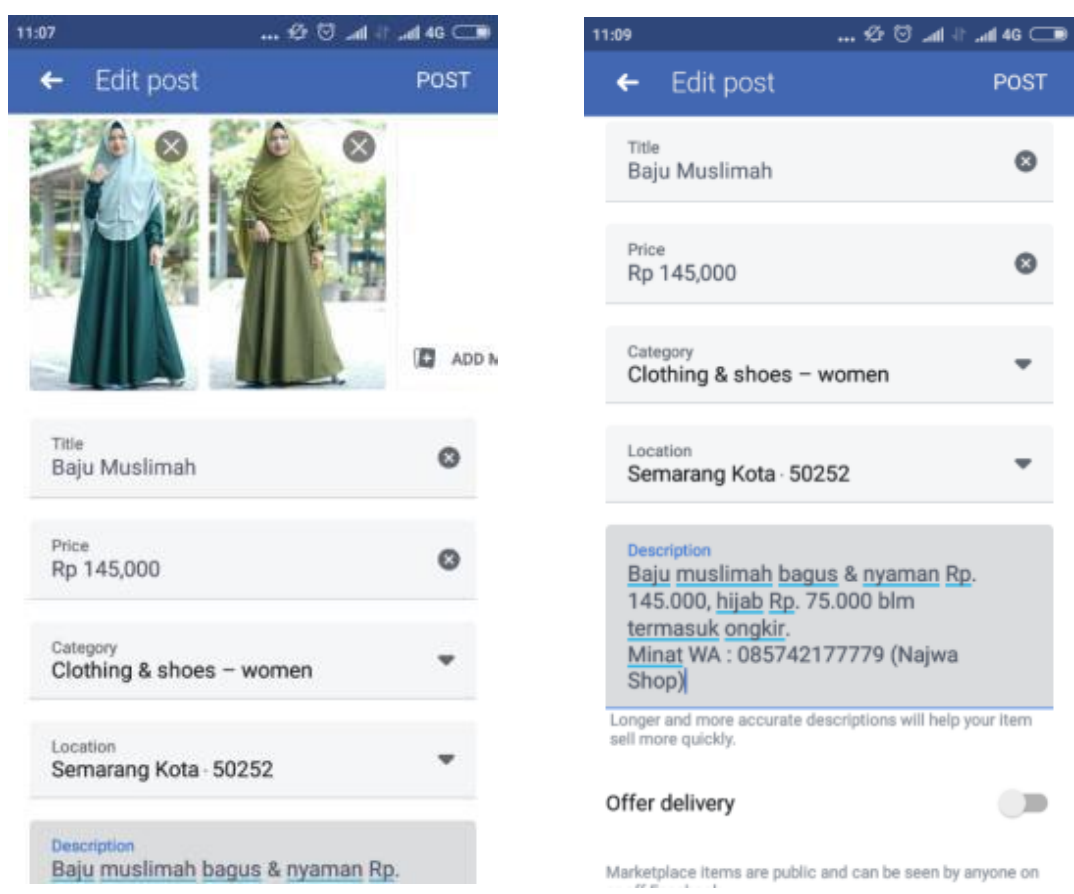

Gambar 8 Halaman isian detail produk

Gambar 7 dan gambar 8 merupakan proses pengisian formulir penjualan produk dari foto produk, judul, harga, kategori, lokasi dan deskripsi produk yang merupakan penjalasan yang nantinya akan dilihat oleh pengunjung di FB Marketplace. 

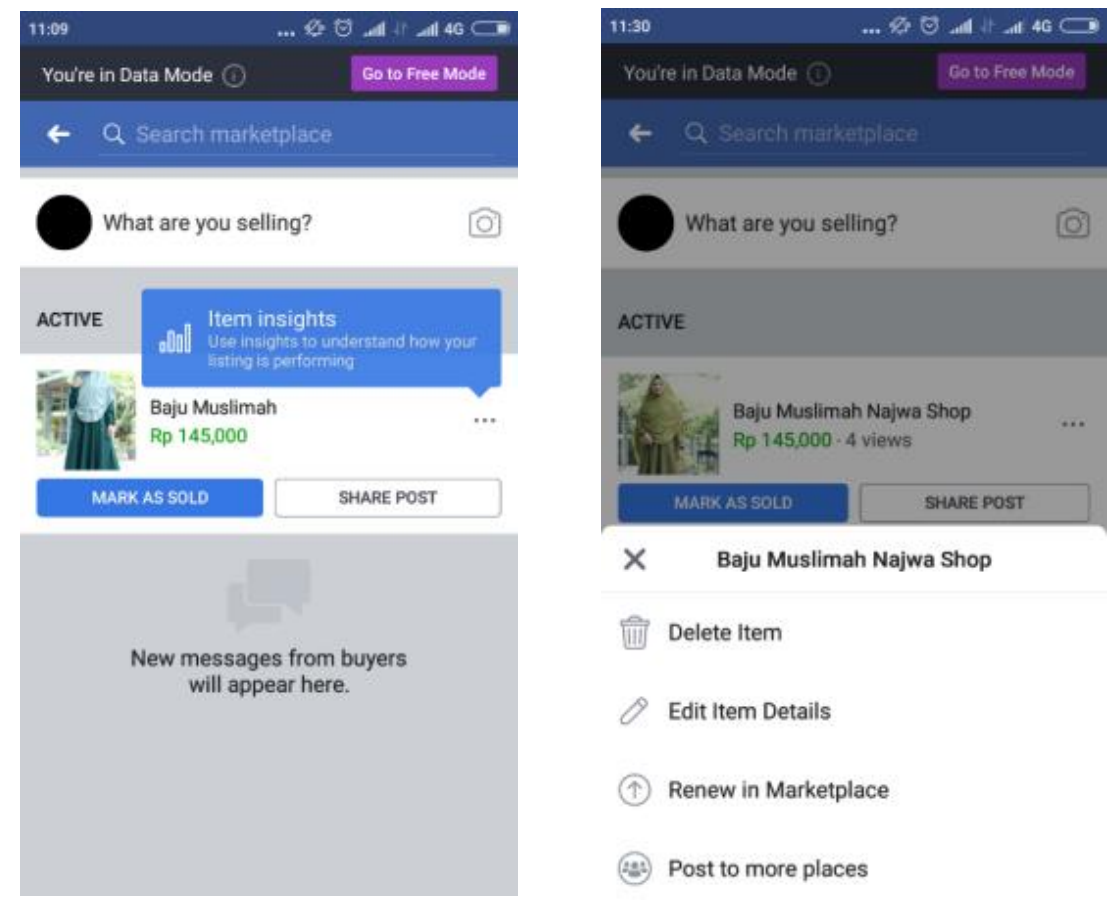

Gambar 9 Halaman daftar produk yang dijual

Gambar 9 menjelaskan daftar produk yang akan dijual dan fasilitas untuk mengedit detail produk jika sudah laku, dihapus, diposting baru lagi atau diposting di tempat lain.
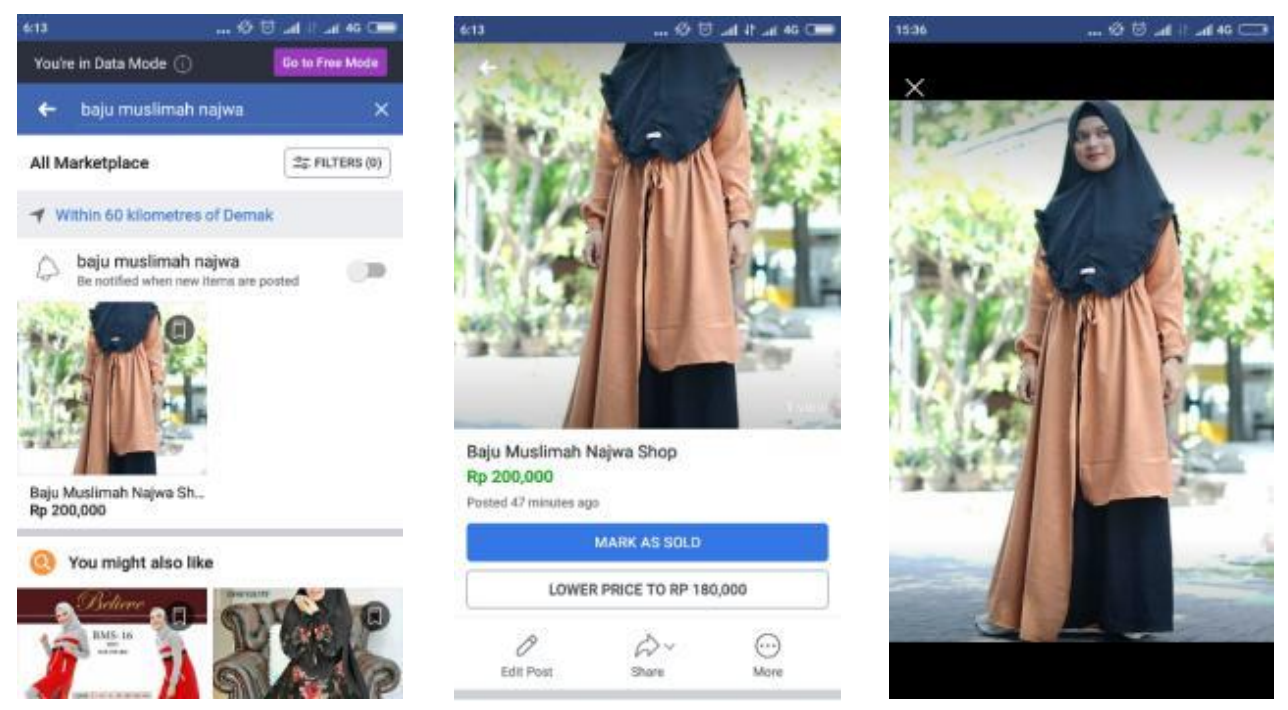

Gambar 10 Halaman pencarian produk

Gambar 10 adalah fasilitas untuk pencarian produk yang sudah diunggah, dapat melakukan pengubahan data, view gallery produk dan membagi ke pengguna lain di FB. 


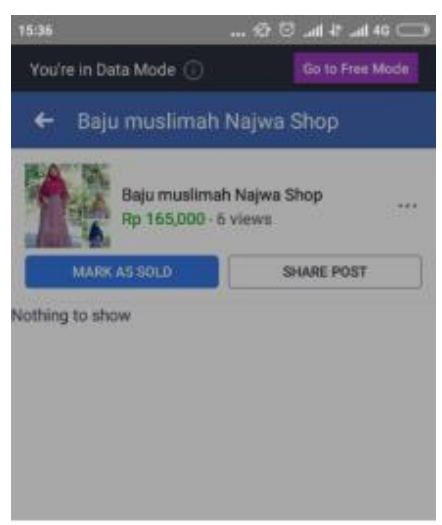

(-) Send in Messenger

10. Write Post

Copy Link

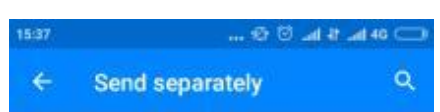

Look at this item I found on Facebook Marketplace, https: //www.facebook.com

marketplace/item/1852418014874838/

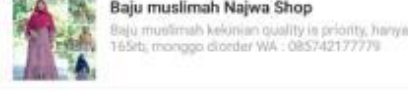

+8. Send to new group

Recent conversations

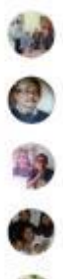

Ahmad Alamsyah QAlameratiab

Pakdhe Phons epakdhephons

38 NviHendriyanto

32 End

(3) Muh Wijaya

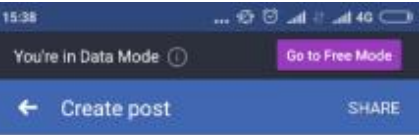

29. Ajib Susanto Ghiyatsi

Baju muslimah kekinian

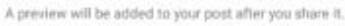

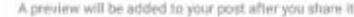

Add to your post

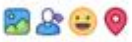

Gambar 11 Halaman untuk berbagi postingan

Dari gambar 11 di atas menunjukkan cara untuk berbagi postingan produk kepada grup FB, ke akun lain atau memposting ke status FB.

\subsection{Evaluasi}

Pada tahap ini memantau perkembangan promosi dan penjualan di Facebook Marketplace dan menentukan hal apa lagi yang dapat digunakan untuk terus meningkatkan promosi dan penjualan online. Hal yang dikerjakan adalah :

a. Mengamati jumlah respon dari pengguna FB untuk produk yang sudah diuanggah.

b. Mengamati periode unggahan produk apakah sudah berpengaruh dengan jumlah penjualan atau orderan, jika belum berpengaruh dapat mengubah periode postingan lebih cept lagi.

c. Menganalisa respon atau tanggapan pelanggan apakah cenderung positif atau negative sehingga dapat dirumuskan langkah untuk mengantisipasinya.

\subsection{Menindaklanjuti}

Pada tahap ini dilakukan tindakan nyata sesuai rekomendasi atau laporan perkembangan setelah dilakukan evaluasi sehingga tujuan yang diharapkan dapat tercapai. Memulai kembali merencanakan, menganalisa dan menindaklanjuti yang disepakati sesuai hasil evaluasi sebelumnya.

\section{KESIMPULAN DAN SARAN}

Dari haasil implementasi FB Marketplace memudahkan pelaku UMKM dalam memasarkan produk dan sekaligus melakukan penjualan dengan menggunakan smartphone yang dimiliki dan dapat dilakukan dimanapun dan kapanpun sehingga mampu meningkatkan volume penjualan. Sebagai upaya peningkatan pemasaran dan penjualan online untuk selanjutnya perlu dilakukan hal serupa untuk media sosial lain seperti di Instagram dan di marketplace lain seperti di Shopee, Tokopedia dan sejenisnya. 


\section{UCAPAN TERIMA KASIH}

Penulis mengucapkan terima kasih kepada Lembaga Penelitian dan Pengabdian Masyarakat (LPPM) Universitas Dian Nuswantoro yang telah memberikan dukungan melalui pendanaan dalam kegiatan pengabdian ini.

\section{DAFTAR PUSTAKA}

[1] Solopos.com-Newswire, "Dinkop Jateng Dorong Pelaku UKM Naik Kelas," 2019. [Online]. Available: https://www.solopos.com/dinkop-jateng-dorong-pelaku-ukm-naikkelas-977682. [Accessed: 11-Oct-2019].

[2] A. Susanto, Wijanarto, and I. Utomo WM, "Rekayasa E-Market untuk Kelompok Usaha Pemuda Binaan Dinas Pemuda Dan Olahraga Propinsi Jawa Tengah sebagai upaya Peningkatan Pemasaran dan Penjualan Produk UMKM,” pp. 251-258, 2014.

[3] B. A. Isnanto, "Daya Tawar Rendah, UMKM di Jateng Didorong Bentuk Koperasi," DetikNews, 2019. .

[4] A. Susanto and F. Budiman, "Rekayasa Model Internet Marketing Pada E-Supermuseum Batik Untuk Meningkatkan Pemasaran Batik Produk Unggulan Ukm Batik Di Jawa Tengah," Semin. Nas. Inform. Yogyakarta, vol. 2013, no. semnasIF, pp. 1979-2328, 2013.

[5] A. Susanto, "Big Data dan Ekonomi Digital," Semarang, 2019.

[6] A. Susanto, Wijanarto, and I. Utomo W.M, "Rekayasa M-MARKET (Mobile Market ) untuk Kelompok Usaha Pemuda Binaan Dinas Pemuda dan Olahraga,” vol. 14, no. 1, pp. $8-12,2015$.

[7] A. A. Maulana, A. Susanto, and D. P. Kusumaningrum, "Rancang Bangun Web Scraping Pada Marketplace di Indonesia," JOINS (Journal Inf. Syst., vol. 4, no. 1, pp. 41-53, 2019.

[8] Wearesocial.com, "Digital in 2019," New York, 2019.

[9] Boby, "Jualan di Facebook Bisa Makin Laris dengan Terapkan Hal-Hal Berikut Ini," moneysmart.id, 2019. [Online]. Available: https://www.moneysmart.id/jualan-difacebook/. [Accessed: 11-Oct-2019].

[10] H. Poerwanto G, "Plan-Do-Check-Act (PDCA)," https://sites.google.com. [Online]. Available: https://sites.google.com/site/kelolakualitas/PDCA. [Accessed: 11-Oct-2019]. 